https://doi.org/10.47669/CEERS-1-2019

\title{
Post-Soviet Organized Crime: Insights from Russia
}

Aram TERZYAN*

This paper explores various dimensions of post-Soviet organized crime in Russia, with a focus on its main implications. Despite its steadily growing relevance, there has been little academic attention to organized crime. Before the 1990s, most organized crime definitions revolved around central characteristics, such as the nature and severity of offenses committed, the numbers of individuals involved, and the enduring nature of the enterprise. There was a breakthrough in 2000, when the United Nations Convention against Transnational Organized Crime (Article 2) defined organized crime broadly "as a structured group of three or more persons existing for a period of time and acting in concert with the aim of committing one or more serious crimes or offenses in accordance with this Convention in order to obtain, directly or indirectly, a financial or material benefit" (United Nations Office on Drugs and Crime, 2000). International representatives at the 2000 meeting, however, came up with a consensus on a definition or a list of criminal acts, but decided to adopt a broad definition of organized criminal groups, while avoiding reductionism to hierarchically structured "mafia-type organizations." Reflecting the changing nature of global organized crime activity, officials began pay

\footnotetext{
* Aram Terzyan, $\mathrm{PhD}$ is research director of Los Angeles-based Center for East European and Russian Studies of Eurasia Institutes. Email: a.terzyan@eurasiainstitutes.org .
} 
more attention on loosely organized criminal groups who committed serious crimes that were transnational in nature (Roth, 2010, pp. 11-12).

Organized crime can be described as an 'unholy alliance' of state, market, and crime, or in other words, a political-business-criminal nexus. It is regarded as a web of affiliations of 'underworld' and 'upperworld' societal participants, who have complicated relations of reciprocity (Kupatadze, 2012, p. 5). These societal participants include people and groups within law enforcement agencies, political parties, the business sector and the crime world (Ibid).

Some students focus specifically on organized crime's use of political corruption and its impact on the economy and civil society, as manifested in the following definition: "Organized crime is crime committed by criminal organizations whose existence has continuity over time and across crimes, and that use systematic violence and corruption to facilitate their criminal activities. These criminal organizations have varying capacities to inflict economic, physical, psychological, and societal harm. The greater their capacity to harm, the greater the danger they pose to society" (Xiao, 2016).

Clearly, corruption and bribery are important tools for organized crime groups. In effect, organized crime thrives in environments where bribery is rampant, and vice versa, and several authors call corruption the 'connecting tissue' between crime and politics (or the 'oxygen' sustaining organized crime (Kupatadze, 2012, p. 5). That said, Russia's being one of the most corrupt countries in post-Soviet space and beyond, would provide a fertile ground for emergence and rapid development of organized crime groups. 
Post-Soviet Organized Crime: Insights From Russia

\section{Russian Organized Crime (ROC)}

The origins of organized crime in Russia, as elsewhere in the former Soviet Union, can be traced back to the Soviet period itself. Between the 1920s and 1990s, Soviet labor camps, or gulags, gave birth to an elite criminal fraternity, or vory-v-zakone, which lived according to a thieves' law, an unwritten system of rules and behavior (Varese, 1998).

Inadequacies of the Soviet system of central planning led to the criminalization of the Soviet economy and the emergence of the thievesin-law as critical players. Activities such as racketeering, robbery, and other crimes were widespread. The roots of the Russian mafia lie in the innermost depths of the Russian shadow economy (Cheloukhine, 2008). The latter took a clear shape during Brezhnev era, characterized by economic downturn and ensuing stagnation. This poor economic context proved conducive to the emergence and growing dependence of institutions upon a rapidly advancing shadow economy that, would be considered necessary for offsetting shortages within the Soviet economy. Meanwhile, the Soviet authorities would take a huge advantage of the shadow economy through extorting money from shadow businessmen for protecting their illegal businesses (Xiao, 2016). However, the authorities were not the only beneficiaries of the shadow economy. Rather, as government officials embarked on providing protection 'from above' in exchange for bribes, criminal groups began providing 'protection services' to shadow businessmen 'from below'. As a result, the interactions between formal and informal institutions intensified dramatically (Ibid). 
According to one expert, ROC groups emerged in the 1960s thanks to a state apparatus that "encouraged, facilitated and protected it" (Roth, 2010, pp. 97-98). During the Brezhnev regime in the 1970s and early 1980s, it became increasingly clear that the country was in the hands of corrupt Communist bureaucrats that some even had the temerity to brand a "kleptocracy." It even became fashionable to call this corruption "Mafiya" (Ibid).

The organized crime groups multiplied after the collapse of Soviet Union, amid large-scale privatization. A well-informed observer notes that "In Soviet times, everything belonged to the people. The change has created the situation where things ceased to be 'ours' but did not become 'mine.' They are nobody's. Now, people have no qualms about destroying something that was created by other people to buy a bottle or support themselves" (Paddok, 1998).

The privatization of state property that began in Russia in 1992when public property began to be sold to private investors-both expanded and solidified the complex relationship that had developed between the state and organized crime. The new gangster class included former KGB agents and military defectors, government specialists, and former prison inmates.

Because of the nature of the post-Soviet transition, criminals won ownership of vast resources and became indispensable instruments of the new 'legitimate' authorities, who needed the criminals' capital and social support, not to mention occasional physical force, to consolidate their political power (Kupatadze, 2012, p. 2). In effect, the assets controlled by organized crime give it enormous economic power, and hence political power as well. 
Post-Soviet Organized Crime: Insights From Russia

Furthermore, organized crime has also attempted to assume certain governmental functions, such as dividing territories among competing economic actors and regulating business markets. It seeks to control business-market entry, to impose taxes (protection fees), through direct violence or other forms of coercion (Finckenauer and Voronin, 2001).

Organized crime in Russia uses legal businesses as fronts for illegal activities and for setting up illegal product lines. It creates "political clans" to exercise political power and seeks to create and regulate markets to exercise economic power.

Although several powerful criminal organizations emerged, there is no evidence that a single gang or group of gangs controls the Russian underworld. Among the few syndicates with a recognizable hierarchy is Moscow's largest group, the Solntsevo, named after the suburb where it was created. In the mid-1990s, it had a reputed 9,000 members, although others place the figure much lower (O'Brien, 2012). According to one leading authority, it functions as an umbrella organization with different crews active in different countries, but it does operate under a supreme council composed of 12 individuals who are considered the leaders of various factions (Roth, 2010, p. 99). It meets on a regular basis. Although size estimates vary for this group, it runs against the typical ROC group profile that officials describe as small in numbers (Ibid). More recently observers have argued that ROC is hardly quantifiable. What has never been made clear is what Russian gangs fell under the rubric of organized crime, whether the various numbers floated about refer to street gangs, 
mafiya clans, criminal societies or associations, or bandit groups. Some scholars have suggested that "the Russian underworld is maturing, as larger, more professional networks" subsume the hundreds of smaller organizations and gangs that emerged in post-Soviet Russia (Ibid).

Overall, Russian criminals have tended to make extensive use of the state governmental apparatus to protect and promote their criminal activities. For example, most businesses in Russia must operate with the protection of a "krysha" (roof). The protection is often provided by police or security officials employed outside their "official" capacities for this purpose. In other cases, officials are "silent partners" in criminal enterprises that they, in turn, protect (Finckenauer and Voronin, 2001). Furthermore, Russian organized crime operates successfully throughout the former Soviet Union, and beyond engaging in such activities as money laundering, drug trafficking, and the illegal sale of weapons (Ibid).

What makes Russian-based organized crime (RBOC) a formidable challenge is the overwhelming evidence of connections between such criminal networks and the Kremlin's state security apparatus, notably the Foreign Intelligence Service (SVR), military intelligence (GRU), and the Federal Security Service (FSB) (Galeotti, 2018).

Strikingly, today, RBOC is responsible for around one-third of the heroin on Europe's streets, a significant amount of non-European people trafficking, as well as most illegal weapons imports (Ibid).

Rampant corruption is one of the biggest reasons why organized crime keeps persisting across Russia. Notably, along with criminals, the Russian state agents have tended to exploit their own criminal opportunities in an increasingly organized way. In 2016, the police raided the apartment of Col Dmitry Zakharchenko, the acting head of a department within the 
Post-Soviet Organized Crime: Insights From Russia

police force's anti-corruption division. There they found $\$ 123 \mathrm{~m}(£ 87 \mathrm{~m})$ in cash. The assumption is that the money was not all his, but rather that he was the holder of the common fund of a gang of oboroten, or "werewolves", as organized crime groups within police ranks are often known (Galeotti, 2017).

Overall, the Russian state remains highly criminalized, while the interpenetration of the criminal 'underworld' and the political 'upperworld' has prompted the regime to use criminals as instruments of its rule. As a result, the malpractices associated with organized crime keep persisting across Russia, with all ensuing repercussions on Russian society in general and businesses in particular.

\section{References}

Cheloukhine, S. (2008). The roots of Russian organized crime: from old-fashioned professionals to the organized criminal groups of today. Crime, Law and Social Change. 50(4-5), pp. 353-74.

Finckenauer, J and Voronin, Y. (2001). The threat of Russian organized crime. US Department of Justice, Office of Justice Programs, National Institute of Justice. Retrieved November 25, 2019, from https://www.ncjrs.gov/pdffiles1/nij/187085.pdf.

Galeotti, M. (2017). Crimintern: How the Kremlin Uses Russia's Criminal Networks in Europe. London: European Council on Foreign Relations.

Galeotti, M. (2018). Gangster's paradise: how organised crime took over Russia. Retrieved November 28, 2019, from https://www.theguardian.com/news/2018/mar/23/how-organised-crimetook-over-russia-vory-super-mafia. 
Kupatadze, A. (2012). Organized crime, political transitions, and state formation in post-Soviet Eurasia. Springer.

O’Brien, M. (2012). Organization attributes Sheet-Solntsevskaya Bratva (Solntsevo Brotherhood). Retrieved November 28, 2019, from http://research.ridgway.pitt.edu/wpcontent/uploads/2012/05/SolntsevskayaBratvaPROFILEFINAL.pdf.

Paddok, R. (1998). In Russia, stealing is a normal part of life. Retrieved November 27, 2019, from https://www.latimes.com/archives/laxpm-1998-sep-21-mn-25012-story.html .

Roth, M. P. (2010). Global organized crime: a reference handbook. Abc-Clio Inc.

United Nations Office on Drugs and Crime (2000). Retrieved November 28, 2019, from https://www.unodc.org/ropan/en/organizedcrime.html .

Varese, F. (1998). The society of the vory-v-zakone, 1930s1950s. Cahiers du monde russe, pp. 515-538.

Xiao, J. (2016). The evolution of Russian organised crime and the challenge to democracy. Retrieved November 29, 2019, from https://www.e-ir.info/2016/07/31/the-evolution-of-russian-organisedcrime-and-the-challenge-to-democracy/. 